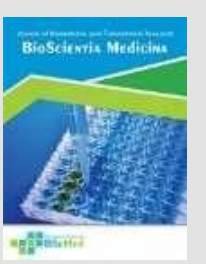

\title{
Prescription Profile of Antibiotic Drugs Post Excision Biopsy of Oral Soft Tissue Disease in Palembang
}

\section{Nadhila Apriadhanti ${ }^{1}$, Nita Parisa ${ }^{2}$, Siti Rusdiana Puspa Dewi ${ }^{1}$}

${ }^{1}$ Dentistry Program, Faculty of Medicine, Universitas Sriwijaya, Palembang, Indonesia

2Department of Pharmacology, Faculty of Medicine, Universitas Sriwijaya, Palembang, Indonesia

\author{
A R T I C L E I N F O \\ Keywords : \\ Amoxicillin \\ Antibiotics \\ Excisional Biopsy \\ Dentist \\ Epulis
}

\section{Corresponding author: \\ Nita Parisa \\ E-mail address: \\ nitaparisa@unsri.ac.id}

All authors have reviewed and approved the final version of the manuscript.

\begin{abstract}
A B S T R A C T
Backgroud: An excisional biopsy is one of the surgical treatments given to cases of small benign tumors in the soft tissues of the oral cavity. Antibiotics are prescribed by dentists as a follow-up therapy after excisional biopsy to prevent bacterial infection. The purpose of this study was to determine the profile of antibiotic drug prescription after excision biopsy of oral soft tissue disease by dentists in Palembang. Methods: This type of research is descriptive observational with a survey method. The research was carried out by distributing questionnaires to 40 dentists and dental specialists in Palembang who had performed excision biopsy treatment for oral soft tissue disease. Result: The results showed that the antibiotic prescription of amoxicillin was $55 \%$, the combination of amoxicillin and clavulanic acid was $17.5 \%$, and clindamycin was $12.5 \%$. The cases found in this study were epulis $57.5 \%$, mucocele $30 \%$, and traumatic fibroma $10 \%$. Conclusion: It can be concluded that the antibiotic most often prescribed by dentists in Palembang after excision biopsy treatment was amoxicillin and the most common case was epulis.
\end{abstract}

https://doi.org/10.32539/bsm.v5i3.215

\section{Introduction}

Excisional biopsy is the removal of all oral lesions. Removal of this abnormal tissue must be accompanied by a little healthy tissue around it to ensure that all abnormal tissue has been removed and prevent recurrence. ${ }^{1-7}$ Lesions that are clinically benign, small (less than $1 \mathrm{~cm}$ ), and easy to reach for surgery are indicated for operation excisional biopsy eg mucocele, fibroma, papilloma, hemangioma, and epulis. ${ }^{7}$ An incisional biopsy is a biopsy technique that is performed by taking a small sample of tissue from a lesion for diagnostic purposes. Large lesions (more than $1 \mathrm{~cm}$ ) and suspected to be malignant, indicated for incision eg lichen planus. A punch biopsy is an alternative technique of incisional biopsy which can be performed if the lesion is difficult to reach. 6
Based on research conducted by A Wan and Savage (2010) in Australia, excisional biopsy was the most frequently performed biopsy procedure, with 289 cases $(68.5 \%)$ in cases of traumatic fibroepithelial polyps or fibroma, while incisional biopsy was 72 cases $(17.1 \%)$, and punch biopsy in 61 cases $(14.5 \%)^{9}$. Based on the study of Claudia et al (2011) in Spain, most of the biopsies (83.9\%) were excisional biopsies, while $16.1 \%$ were incisional biopsies. 10

Some of the risks that can occur after surgery (excisional biopsy) are infection, pain, and bleeding. Infection is a condition where microorganisms enter and develop in the host's body, so that it can cause pain accompanied by local or systemic clinical symptoms. 
Wounds on the body provide opportunities for bacteria to enter and increase the risk of infection, so postsurgical antibiotic and anti-inflammatory drugs are needed. ${ }^{11-13}$

Based on the study by Palmer et al (2009) in the UK, the antibiotic prescribed by dentists in the UK was amoxicillin as the main antibiotic of choice, which was $70.5 \%$, followed by penicillin $\mathrm{V}$ by $20.5 \%$, and metronidazole by $7 \%{ }^{14}$. Based on the research of Garg Amit et al (2014) in India, 73.4\% of respondents chose amoxicillin for non-allergic patients (single 50.5\% and a combination of clavulanic acid 22.8\%). 15 In the study of Sinan Sermet et al (2011) in Turkey, a combination of amoxicillin and acid Clavulanate was the antibiotic of choice in periodontal procedures, namely $17.3 \%$, followed by amoxicillin at $14 \%$. The combination of amoxicillin and clavulanic acid is also the main antibiotic of choice in surgical procedures, namely $22.8 \%$, followed by amoxicillin at 20.5\%, and clindamycin $14.9 \%$. The choice of antibiotics is also based on clinical conditions and the types of microorganisms present so that the antibiotics that are often used are broad-spectrum antibiotics. 16

Anti-toxic use is required and indicated in certain cases. One of them, the use of antibiotics is used as a follow-up treatment of the excisional biopsy procedure to prevent post-surgical infection. This study is the first study conducted to conduct surveys and studies to determine the percentage of antibiotics that are widely used in excisional biopsy cases.

\section{Methods}

This type of research is a descriptive observational survey type. A total of 40 dentists consisting of 11 specialist dentists and 29 general dentists in Palembang were distributed questionnaires to find out which antibiotic drugs are often prescribed after excision biopsy of oral soft tissue disease. The inclusion criteria were dentists - specialist dentists registered with the Palembang City Health Service and dentists - specialist dentists who had performed an excisional biopsy. The exclusion criteria were dentists - specialist dentists who were unwilling to participate in the study.

The data were collected using a questionnaire form which was filled in by the respondents in this study who were a dentist and a specialist dentist in Palembang. The questionnaire consisted of several questions that were considered representative to determine the profile of antibiotic drug prescription after excision biopsy of oral soft tissue disease given by dentists and / or specialist dentists in Palembang. The data obtained from questionnaires that have been filled in, collected, processed, and analyzed are simply presented in tabular form and described based on the answers to the questionnaire.

\section{Results}

Table 1 shows that amoxicillin is the antibiotic drug most often prescribed by dentists in Palembang City after excision biopsy of oral soft tissue disease, as many as 22 of 40 dentists (55\%) with a dose of $500 \mathrm{mg}$ and the rule of use 3 times a day. The amoxicillin-clavulanic acid combination was prescribed by 7 of 40 dentists (17.5\%) and clindamycin was prescribed by 5 of 40 dentists $(12.5 \%)$.

Table 2 shows that antibiotic drugs with tablet preparations are the main choice of dentists in Palembang city to be given to patients after excision biopsy of oral soft tissue disease, as many as 34 out of 40 dentists $(60 \%)$, while capsules were used by 6 dentists (15\%).

Table 3 shows the number of cases or soft tissue diseases of the oral cavity given excision biopsy treatment by dentists in Palembang. The most frequent cases found by dentists were epulis with 23 cases $(57.5 \%)$. Mucoceles were also frequently seen by dentists in 12 cases (30\%). Hemangioma is the rarest disease, only 1 dentist (2.5\%) performed an excisional biopsy in cases of hemangioma. 
Table 1. Distributiona of prescription antibiotic drugs post-excision biopsy of oral soft tissue by dentists in Palembang

\begin{tabular}{lcccc}
\hline Antibiotics & Frequency & $\begin{array}{c}\text { Percentage } \\
\text { (\%) }\end{array}$ & Dosage (mg) & $\begin{array}{c}\text { Rules of use } \\
\text { (times / day) }\end{array}$ \\
\hline Amoxicillin & 22 & 55 & 500 & 3 \\
\hline $\begin{array}{l}\text { Amoxicillin-clavulanic acid } \\
\text { combination }\end{array}$ & 7 & 17.5 & 625 & 3 \\
\hline Clindamycin & 5 & 12.5 & 300 & 3 \\
\hline Cefixime & 2 & 5 & 100 & 2 \\
\hline Cefadroxil & 2 & 5 & 500 & 3 \\
\hline $\begin{array}{l}\text { Amoxicillin-metronidazole } \\
\text { combination }\end{array}$ & 1 & 2.5 & 625 & 3 \\
\hline Metronidazole & 1 & 2.5 & 500 & \\
\hline Total & 40 & 100 & & \\
\hline
\end{tabular}

Table 2. Frequency Distribution of antibiotic drug preparations

\begin{tabular}{lcc}
\hline Drug preparations & Frequency & Percentage (\%) \\
\hline Tablet & 34 & 60 \\
\hline Capsule & 6 & 15 \\
\hline Total & $\mathbf{4 0}$ & $\mathbf{1 0 0}$ \\
\hline
\end{tabular}

Table 3. Frequency distribution of oral soft tissue diseases

\begin{tabular}{lcc}
\hline Oral soft tissue disease & Frequency & Percentage (\%) \\
\hline Epulis & 23 & 57.5 \\
\hline Mukokele & 12 & 30 \\
\hline Traumatic fibroma & 4 & 10 \\
\hline Hemangioma & 1 & 2.5 \\
\hline Total & $\mathbf{4 0}$ & $\mathbf{1 0 0}$ \\
\hline
\end{tabular}

\section{Discussion}

This study involved 40 dentists registered at the Palembang City Health Office, namely 29 general dentists and 11 specialist dentists who both worked in hospitals and private practices in Palembang City who had performed excisional biopsy of oral soft tissue diseases. Based on table 4.1, it shows that out of 40 dentists, 22 dentists (55\%) chose to prescribe amoxicillin antibiotics, 7 dentists (17.5\%) prescribed amoxicillin-clavulanic acid combination antibiotics and 5 dentists (12.5\%) prescribe clindamycin. This result is similar to that of Palmer et al. (2009) in the UK, who reported that amoxicillin was the main antibiotic drug of choice prescribed by dentists, namely $70.5 \% 14$. Research by Sinan Sermet et al (2011) in Turkey also reported that the combination of amoxicillin and clavulanic acid was the antibiotic of choice in surgical procedures, namely $22.8 \%$, followed by amoxicillin at
$20.5 \%$, and clindamycin $14.9 \% 60$

The choice of antibiotics is viewed from several factors, including the spectrum and sensitivity pattern of bacteria causing infection, the results of microbiological and bacterial incision causes, the pharmacokinetic and pharmacodynamic profiles of drugs, and the cost effectiveness or price of drugs.13,15,60 Microbiological examination is an important thing to do to determine infection-causing bacteria and sensitivity to infection-causing bacteria, but this examination is costly and of course takes time. 60 In order to overcome the possibility of infection that can occur after an excisional biopsy, antibiotics should be given as possible. This can be a reason for dentists to choose antibiotics based on professional knowledge and experience, so that dentists generally choose broad-spectrum antibiotics that are effective against both gram-positive and gram-negative bacteria. 
Amoxicillin is a penicillin antibiotic from the betalactam class that is most often prescribed because it is a broad-spectrum antibiotic that is effective against gram-positive and gram-negative bacteria. Amoxicillin is a bactericidal antibiotic that effectively kills bacteria. 12,13,14,16,20 Dentists also argue that amoxicillin has an affordable price and is widely available in the market so it is more widely chosen. Amoxicillin has adequate pharmacokinetic and pharmacodynamic properties and the standard drug dosage 13,60 is $500 \mathrm{mg}$ orally every 8 hours or 3 times a day for adults, and $250 \mathrm{mg}$ every 8 hours for children. ${ }^{54}$

Judging from the pharmacokinetic properties of the drug, amoxicillin is absorbed quickly and well through oral administration and is not disturbed by the presence of food. Amoxicillin has a high bioavailability of $74-92 \%$ with peak plasma levels occurring within 1-

2 hours. Amoxicillin is most widely distributed in the body and bones and in tissues including the lungs, bronchial secretions, bile, pleura and middle ear fluid. Amoxicillin can cross the placental barrier so that it can be consumed by pregnant women. Metabolism of this drug occurs in the liver with a pulmonary time of about 1 hour in adults and shorter in children. Amoxicillin is secreted in urine about $86 \%$ and the clearance is $10.8 \mathrm{~L} / \mathrm{h} / 70 \mathrm{~kg} \cdot{ }^{13,54}$ Pharmodynamically, amoxicillin has a long therapeutic effect. Amoxicillin is a penicillin derivative that is resistant to acid and is stable in acidic stomach conditions, but is sometimes resistant to penicillinase. Amoxicillin has a bactericidal effect that actively makes bacteria into lysis by inhibiting cell wall biosynthesis. 12,14,54

Some dentists prescribe a combination of amoxicillin and clavulanic acid as an option for postexcisional biopsy therapy. This is supported by research conducted by Sinan Sermet et al (2011) that the combination of amoxicillin and clavulanic acid is the antibiotic of choice prescribed by dentists in surgical cases. ${ }^{60}$ Clavulanic acid is often combined with amoxicillin in order to reduce drug resistance and increase antibiotic activity. This combination of drugs is also thought to have a synergistic effect so that it can accelerate the healing of infection. ${ }^{12,14,60}$ The combination of amoxicillin and clavulanic acid is prescribed at a dose of $625 \mathrm{mg}(500 \mathrm{mg}$ of amoxicillin and $125 \mathrm{mg}$ of clavulanic acid) with a rule of use 3 times a day according to the rules of use and standard dose for adults.

Clindamycin is also an antibiotic that is prescribed by some dentists as a follow-up therapy after excisional biopsy. Clindamycin is an antibiotic that has a limited spectrum of action and is effective against gramnegative bacteria, but it can weaken some grampositive bacteria. Clindamycin can be an alternative antibiotic for patients who have a penicillin allergy.

Antibiotics that are also prescribed by dentists as post-excision biopsy therapy are cephalosporins and metronidazole. Some types of antibiotics are very rarely prescribed possibly because of the narrow and limited working spectrum of antibiotics for certain types of bacteria, as well as the serious side effects caused by the antibiotics themselves.

Cefixime and cefadroxil are cephalosporin class antibiotics which are broad-spectrum antibiotics and are effective against most gram-negative bacteria. Cefixime is a class III cephalosporin that is active in most gram-negative bacteria, so it can be an option for post biopsy therapy excision of oral soft tissue disease. Cefixime is more indicated for the treatment of severe infections and the price is relatively expensive, so this drug is rarely prescribed by dentists. Cephalosporins can cause hypersensitivity reactions that are identical to those in the penicillin class, so this antibiotic is also contraindicated in patients allergic to penicillin. Metronidazole is an antibiotic that can be combined with amoxicillin, but its single use is rarely prescribed because of its limited spectrum of action.

Based on table 2, overall the antibiotic preparations prescribed by dentists after excision biopsy of oral soft tissue disease are oral preparations. The most common form of oral antibiotic dosage forms is tablets, accounting for $60 \%$. The oral route of drug administration should be the first choice for infection. 54 Drugs can be absorbed better and faster in oral administration 13,15 and oral preparations also have an affordable price compared to injection preparations. 
Dentists also argue that tablet preparations are the most familiar drug preparations among the public, are easy to sell, and are widely available in the market.

Based on table 3, epulis was the most common case in excisional biopsy, which was $57.5 \%$. Epulis is a benign tumor lesion which is generally caused by hormonal factors, oral hygiene, irritation, and physical trauma. 32,33,38,44,47 Several types of epulis can occur at any age. 38,41 Based on the results of the Ministry of Health of the Republic of Indonesia (RIKESDAS) in 2018, the proportion of dental and oral health problems in the province of South Sumatra is still relatively large, namely around $50 \%$ of the population.

Lack of public awareness and knowledge to maintain oral hygiene is suspected to be the cause of the many cases of epulis that occur. Pyogenic granuloma (epulis gravidarum) is a type of epulis that occurs due to local irritation in the form of plaque and calculus, and hormonal changes that occur during pregnancy are thought to trigger the formation of lesions. Some types of epulis can disappear on their own with the loss of etiological factors and the patient's age, but in most cases, epulis can interfere both aesthetically and functionally. This allows epulis to be one of the most common lesions in excisional biopsy cases.

\section{Conclusion}

The most widely used prescription of antibiotic drugs after excision biopsy of oral soft tissue disease by dentists in Palembang was amoxicillin, followed by a combination of amoxicillin-clavulanic acid and clindamycin. The rules for use and the dosage of drugs prescribed by the dentist after excision biopsy are given according to the rules of use and the standard dosage of the drug. The most widely prescribed antibiotic preparations by dentists are tablets.

\section{References}

1. Nikitakis NG. Oral soft tissue lesions: A guide to differential diagnosis Part II: Surface alterations. Braz J Oral Sci. 2005 March 7;4(13):707-15
2. Goyal S, Shetty A, Singla I, Singla S, Verma A. Injuries to Oral Soft Tissues by Different Factors: A Clinical Study. Indian J Multidiscip Dent. 2016 July;23;6(1):7-10

3. Nikitakis NG. Oral soft tissue lesions: A guide to differential diagnosis Part I: Introduction and changes in color. Braz J Oral Sci. 2003;2(6)

4. Oliver R.J, Sloan P, Pemberton MN. Oral biopsies: methods and applications. British Dental Journal 2004;196(6)

5. Ali. F.M, Prasant. MC, Pati. A, Ahere. V, Tahasildar. S, Pati. K, Deshpande. R. Oral Biopsy in General Dental Practice: A Review. International Journal of Medicine and Public health [Int. J. Med. Public health] 2012;(2)

6. Logan. RM, Goss. AN. Biopsy of the oral mucosa and use of histopathology services. Australian Dental Journal 2010;55:(1 Suppl): 9-13.

7. Molly S. Rosebush, K. Mark Anderson. Swati Y. Rawal, Harry H. Mincer, Yeshwant B. Rawal. The Oral Biopsy: Indications, Techniques and Special Considerations. The Journal of the Tennessee Dental Association 2010; 90-2

8. Catherine F. Poh, Samson Ng, Kenneth W. Berean, P. Michele Williams, Miriam P. Rosin, Lewei Zhang. Biopsy and Histopathologic Diagnosis of Oral Premalignant and Malignant Lesions. JCDA. 2008;74(3)

9. Wan A, Savage NW. Biopsy and diagnostic histopathology in dental practice in Brisbane: usage patterns and perceptions of usefulness. Australian Dental Journal 2010; 55: 162-169

10. Garibay CF, Nieves A, Leonardo B, Cosme G. Prevalence of biopsied oral lesions in a Department of Oral Surgery. J Clin Exp Dent. 2011;3(2):e73-7.

11. Agustina E, Syahrul F. The Effect of Operating Procedure with Infection Incidence on Contaminated Cleaning Operating Patients (Case Control Study in RSU HAJI Surabaya). Jurnal Berkala Epidemiologi 2017; 5(3):351-60 
12. Roda RP, Bagán JV, Bielsa JMS, Pastor EC. Antibiotic use in dental practice: A review. Med Oral Patol Oral Cir Bucal 2007;12:E186-92.

13. Suardi HN. Antibiotik dalam Dunia Kedokteran Gigi. Cakradonya Dent J. 2014; 6(2):678-744

14. Palmer NA, Pealing R, Ireland R, Martin M. A study of therapeutic antibiotic prescribing in National Health Service general dental practice in England. British Dental Journal 2000; 188: 554-558.

15. Garg Amit, Agrawal N, Tewari RK, Kumar A, Chandra A. Antibiotic prescription pattern among Indian oral healthcare providers: a cross-sectional survey. J Antimicrob Chemother 2014; 69: $526-528$

16. Demirbas F, Gjermo P, Hans R. Antibiotic prescribing practices among Norwegian dentists. Acta Odontologica Scandinavica, 2006; 64: 355-359

17. Valerio RA, de Queiroz AM, Ramoualdo PC, Luiz G, Brentegani LG. Mukokel and Fibroma: Treatment and Clinical Features for Differential Diagnosis. Brazilian Dental Journal 2013; 24(5);537-41

18. Badjatia RG, Badjatia S, Kulkarni VK, Divya SS. Oral Mukokel: A Case Report. NJDSR. 2014;1(2)

19. Daniel JS, Al Bakri IM. Mukokel of lingual glands of Blandin and Nuhn: A report of 5 cases. The Saudi Dental Journal 2009

20. Gupta B, Anegundi R, Sudha P. Mukokel: two case reports. JOHCD. 2007;1(3)

21. Setiawan D, Bambang D, Elizabeth T. Eksisi mucocele rekuren pada ventral lidah dengan anestesi lokal. MKGK. April 2016; 2(1): 1-6

22. Vujhini SK, Reddy ES, Sudheer MVS , Katikaneni HK. Irritation fibroma of tongue: a case report. Int $J$ Res Med Sci. 2016 Apr;4(4):1272-1273

23. Bhayade S, Chandak S, Bhondey A, Atulkar M, Sawakar P. Traumatic Fibroma-A Rare Soft Tissue Entity in a Pediatric Patient. Int J Oral Health Med Res. 2015;2(4):52-4
24. Singh N, Shivaprasad B, Savita S. Traumatic Fibroma: A Case Series. Journal of Health Sciences \& Research. January-June 2016;7(1):28-31

25. Kalkur C, Nilofer H. Haemangioma on Tongue: A Case Report. JOJ Case Stud. 2018; 8(2): 555733

26. Rashmi G, Dilip SS, Sidharatha A, Wasim K. A review of Hemangioma of the Oral Cavity. Unique Journal of Medical and Dental Sciences $2015 ; 3(4): 4-6$

27. Corrêa PH, Nunes LCC, Johann ACBR, Aguiar MCF, Gomez RS, Mesquita RA. Prevalence of Oral Hemangioma, Vascular Malformation and Varix in A Brazilian Population. Braz Oral Res 2007;21(1):40-5

28. Silva FW, Querioz AM. Oral Papilloma in Pediatric Patients. Braz J Oral Sci. 2006;5(16):938-40

29. Ilea A, Boșca B, Miclăuș V, Rus V, Băbțan AM, Mesaros A, Crișan B, Câmpian RS. Oral Human Papillomavirus Infection In Children. The Pediatric Infectious Disease Journal 2015; 35(2)

30. Carneiro T, Sandra A, Flaviana D, Ana T, Nádia L, João L. Oral squamous papilloma: clinical, histologic and immunohistochemical analyses. Journal of Oral Science 2009; 51(3):367-372

31. Kumar BP, Tanya K, P. Ramaswamy, Pattipati S, Sudhakar, Geethika V. Squamous papilloma: Report of two cases. J. Stomat. Occ. Med. 2013; 6:106-109

32. Wollina U, Langner D, França K, Gianfaldoni S, Lotti T, Tchernev G. Pyogenic Granuloma - A Common Benign Vascular Tumor with Variable Clinical Presentation: New Findings and Treatment Options. Open Access Maced J Med Sci. 2017 Jul 25;5(4):423-26.

33. Hanriko Rizki. Granuloma Piogenik pada Gingiva. JK Unila 2016 Oktober;1(2)

34. Hopkal, Korniecka J, Szyszkowska AM, Hopkala M, Koszel UO, Czajkowski L. Observation on Epulis Based on Clinical 
Material with a Focus on Histopathological Diagnosis. Dental Surgery Department, Conservative Dentistry Department Medical University of Lublin 2007; 1(67): 127-30.

35. Kamal R, Parveen D, Abhiney P. Oral pyogenic granuloma: Various concepts of etiopathogenesis. J Oral Maxillofac Pathol. 2012 Jan-Apr; 16(1): 79-82.

36. Patil K, Ketki, Vinayak D, Kanakdande. Peripheral giant cell granuloma: A comprehensive review of an ambiguous lesion. Journal of the International Clinical Dental Research Organization 2014; 6(2)

37. Nekouei A, Alireza E, Parisa J, Zahra E. A Review and Report of Peripheral Giant Cell Granuloma in a 4-Year-Old Child. Torabinejad Dental Research Center and Department of Pediatric Dentistry 2016

38. Laus M, Manuel A, Adelchi C. Giant Fibrous Epulis: A Case Report of a Benign Mass of the Oral Cavity. International Journal of Otolaryngology and Head \& Neck Surgery 2016; 5:228-232

39. Kaustubh P, Ketki P, Vinayak D. Peripheral giant cell granuloma: A comprehensive review of an ambiguous lesion. Journal of the International Clinical Dental Research Organization 2014; 6(2)

40. Ghadimi S, Nasim C, Mahsa N, Sepideh A. Peripheral giant cell granuloma: A comprehensive review of an ambiguous lesion. Journal of Lasers in Medical Sciences 2015; 6(2)

41. Praba FW, Bambang D. Penatalaksanaan Ekstirpasi Epulis Fibromatosa Ukuran Besar pada Gingiva Rahang Bawah Kanan dengan Anastesi Lokal. Maj Ked Gr. 2012; 19(1): 58-61

42. Manovijay B, Rajathi P, Saramma M, Sekar. Recurrent epulis granulomatosa: A second look. Journal of Advanced Clinical \& Research Insights 2015; 2:140-14

43. Ghadimi S, Nasim C, Mahsa N, Sepideh A. Excision of Epulis Granulomatosa with Diode
Laser in 8 Years Old Boy. Journal of Lasers in Medical Sciences 2015; 6(2)

44. Mortazavi H, Hamid R, Soudeh J, Maryam B. Epulis fissuratum in the soft palate: Report of a case in a very rare location. Dent Hypotheses 2016;7:67-9

45. Monteiro Luis S, João M, Ana A, Câmara M, Marco A, José M. Treatment of Epulis Fissuratum with Carbon Dioxide Laser in a Patient with Antithrombotic Medication. Braz Dent J. 2012; 23(1): 77-81

46. Mohammadi M, Nader N, Mohammad Reza. Clinical and denture-related characteristics in patients with epulis fissuratum: a retrospective 58 case series. Caspian J Dent Res. 2017;6(1): 15-21

47. Pekçetin Z, Ayşegül S, Gizem E, Selin K, Mehmet Y, Meltem K. Congenital Epulis of the Newborn: A Case Report. Open Journal of Stomatology 2018; 8:120-126

48. Kumar R, Radhika M, Rashi S. Congenital epulis of the newborn. J Oral Maxillofac Pathol. $2015 ; 19(3): 407$.

49. Zargaran M. A Review of Biopsy in Dentistry: Principles, Techniques, and Considerations. JDMT. June 2014; 3(2)

50. Singh H, Shalini, Charay N, Poonia M. Biopsy - A Vision of Life. International Journal of Contemporary Med Res. 2016 June;3(6):173437

51. Lynch D, Laura F. The oral mucosal punch biopsy: indications and technique. JADA. 1990. $121 ; 145$

52. Shalley S, Nasib C, Amit A, Laxmi N, Varuni Y, Aashit Y. Diagnostic Accuracy of Fine Needle Aspiration Cytology in Lesions of Oral Cavity and Salivary Glands: A Clinico-Pathological Study. The Open Dentistry Journal 2018;12(782-90)

53. Singh S, Natasha G, Rajeev S. Fine needle aspiration cytology in lesions of oral and maxillofacial region: Diagnostic pitfalls. J Cytol. 2011 Jul-Sep; 28(3): 93-7 
54. Peraturan Menteri Kesehatan Republik Indonesia Nomor 2406/MENKES/ PER/XII/2011. Pedoman Umum Penggunaan Antibiotik. Jakarta; 2011

55. Sweeney LC, Dave J, Chambers P, Heritage J. Antibiotic Resistance in General Dental Practice-A Cause for Concern? Journal of Antimicrobial Chemotherapy 2004; 53: 567-76

56. Kester M, Karpa KD, Vrana KE. Treatment of Infectious Diseases. Penn State College of Medicine 2012: 41-78

57. Stevens, DL. The Role of Vancomycin in the Treatment Paradigm. Clin Infect Dis. 2006;42(1):51-7
58. Raini M. Antibiotik Golongan Fruokuinolon: Manfaat dan Kerugian. Media Litbangkes. 2016;26(3): 163-174

59. Vyas T. Biopsy of Oral Lesion -A Review Article. Journal of Advanced Medical and Dental Sciences Research 2016;6(1): 76-7

60. Sermet S, Akgun MA, Simsek SA. Antibiotic Prescribing Profile in The Management of Oral Diseases Among Dentists in Istanbul. Journal of Marmara University Institute of Health Sciences $2011 ; 1(1): 35-41$ 